\title{
Shifting Tides: The Potential and Limitations of Critical Mass to Change Discipline Research Habits
}

\author{
Sereana Naepi
}

\begin{abstract}
As we consider the future of Pacific scholarship in Aotearoa-New Zealand it becomes vital to consider what we wish that future to look like and how to get there. Part of that talanoa involves considering what the possible levers of change are and whether they are capable of fulfilling our desires for change. This article outlines the different national interventions that are being made to increase Pacific engagement in Aotearoa-New Zealand's universities, and then considers whether these interventions are fulfilling our vision for our communities. In order to deepen conversations in this space, this article also draws on critical university studies literature to help unpack the current situation and to provoke some questioning around our current trajectory.
\end{abstract}

\section{Introduction}

Many Pacific scholars are searching for change within Aotearoa-New Zealand's university system. However, there is disagreement about what that change should look like and what is necessary to bring about that change. This is not new, and like any heterogenous group of thinkers and communities it is unlikely that we will reach a consensus that leaves every voice heard, every perspective considered, and every approach validated. However, as we move forward, it becomes increasingly important that we create spaces for us to have talanoa about our aspirations and actions so that we can collectively agree on an imperfect plan together.

Part of this talanoa means opening space to have critical conversations about current mechanisms for change which, although partly successful, fall short of expectations. This article takes on the idea of parity or population matching as an option for changing our universities. Fundamentally, this article uses a critical university studies lens to ask at what point will we see change in our university system, and what mechanisms are in place currently to drive this change. In order to open up this conversation, it is first necessary to discuss the context of Pacific communities within our current university system.

\section{Context}

Commitments to Pacific Communities in New Zealand's Universities

The underserving of Pacific communities by New Zealand's higher education sector has been of concern for a number of years. The 2013-2017 Pacific Education Plan aimed for at least parity in all aspects of education for Pacific peoples. ${ }^{1}$ The most recent Pacific Education Action Plan calls for addressing structural bias that prevents Pacific success. ${ }^{2}$ Importantly, the report that informs and provides explanation for the plan outlines that 'in spite of universities' public commitment to supporting Pacific peoples in tertiary study, a substantial amount of work is needed to address the 'white masculine imprint' on university structures." 3 This indicates a shift towards an expectation that education institutions address the foundational structures that operate to exclude Pacific peoples. In light of these expectations, universities across AotearoaNew Zealand have made different commitments to Pacific communities that are primarily focussed on the politics of inclusion. ${ }^{4}$ 
In terms of actioning the government's vision, the Tertiary Education Commission (TEC) provides focused funding for universities per Pacific equivalent full time enrolment (EFT). ${ }^{5}$ This consists of $\$ 135$ per EFT at level 5 and 6 qualifications, $\$ 325$ per EFT at level 7 , and $\$ 450$ per EFT at level 8. ${ }^{6}$ This means that in 2020, the University of Auckland-which reported 2843 Pacific EFTs, of which 86.3 percent were below level 7 qualifications and 4 percent level 7 or above - would have received in the realm of $\$ 747,000$ in additional Tertiary Education Equity Funding to support Pacific student success. ${ }^{7}$ This funding is provided with the expectation that universities will in turn provide the support required for learner success. ${ }^{8}$ Universities are required to provide reports of how they use their equity funding, and to meet minimum standards outlined by TEC, or they risk losing their funding.

\section{Pacific Peoples in New Zealand's Universities}

Pacific peoples are excluded and underserved by our current university system. This is evident within both qualitative and quantitative research. ${ }^{9}$ Significantly, solutions for this problem have traditionally focused on pedagogical approaches and knowledge inclusion. ${ }^{10}$ Both of these focuses mean that Pacific academics within the academy are a crucial touchstone for change. Currently, however, Pacific academics make up less than 1 percent of Aotearoa-New Zealand professors and 1.7 percent of academics. ${ }^{11}$ Pacific students are also underserved within our universities, with Pacific students having lower completion and retention rates than other students. $^{12}$

Despite significant research and investment into recruiting, retaining, and graduating Pacific students from our universities, there continues to be a gap between Pacific students and others. Pacific students have reported that their experiences within the university can be negative. ${ }^{13}$ As a result, there has been further research into what we can do as universities to be more inclusive of Pacific peoples. ${ }^{14}$ Although there has been a rise in Pacific achievement in the last decade, research has highlighted that in the fields of society and culture, and the natural and physical sciences, this increase in achievement is mirrored by the whole student body, so the "achievement gap" persists. ${ }^{15}$

Pacific academic staff have reflected on their experiences within our New Zealand universities. Kidman and Chu highlighted how Pacific staff are isolated within New Zealand's universities and rarely included within "prestige economies" or elite scholarly networks. ${ }^{16}$ Recent studies have also highlighted the disparity of women's experiences in universities around parental leave, and of Pacific women's experiences specifically, which highlights how Pacific women experience the devaluing and exclusion of Pacific knowledges, excess labour expectations, exclusion, isolation, and expectations of gratitude when they are included. ${ }^{17}$ Pacific early career researchers have also outlined how they experience New Zealand universities, noting that, despite universities undervaluing Pacific knowledges, Pacific early career researchers continue to use Pacific knowledges to guide their pedagogical practices. ${ }^{18}$ The experiences outlined in these projects are tied back to neoliberalisation, foundational whiteness in our institutions, and the colonial project. ${ }^{19}$ These foundational values within our university system contribute to the underrepresentation, exclusion, and devaluing of Pacific communities, and need to be disrupted if we are going to see any change. Pacific early career researchers have outlined how, even with the best intentions, engaging in radical decolonial pedagogies is limited by the university's foundational structures. ${ }^{20}$ The polite politics of inclusion do not challenge the structural bases of exclusion and so have not fundamentally shifted Pacific inclusion in the last decade. As the Performance-Based Research Funds (PBRF) review discussed below shows, the continuation 
of these polite politics mean that Pacific peoples will be waiting over three generations for representational change. ${ }^{21}$

\section{Performance-Based Research Fund Changes}

The changes in the PBRF system provide interesting contextual analysis for this article. The PBRF system is a national system that ranks every researcher working in a tertiary education organisation (TEO) in the country and then, dependent on that ranking, provides funding to the institution. It was introduced as a way to reward TEOs that were ensuring that they conducted excellent research and had researcher-led teaching. In 2020-2021 the government forecast that this fund would be $\$ 321$ million. $^{22}$

Importantly, over 2019-2020, there was a review of the PBRF system that proposed and had accepted significant changes to the allocation of funds. Relevant to this article was the commitment to "supporting Pacific researchers and research in the PBRF by increasing from 1 to 2.5, the subject area weighting for Evidence Portfolios assessed by the Pacific Research panel and applying a funding weighting of 2 for Evidence Portfolios submitted by Pacific staff." ${ }^{23}$ Effectively, this resulted in Pacific research and Pacific researchers being more valuable to the university, as they bring in additional points above and beyond other researchers or fields. This shifting of value of not just Pacific research but also Pacific staff followed on from research that showed our research sector did not reflect our society. Importantly for the arguments below, the PBRF review referenced papers that utilised quantitative measures and the review itself utilised "gap" language and population matching to advance their arguments for a more equitable workforce. ${ }^{24}$ After covering the quantitative inequity within the sector, the report outlined scholarship that showed structural discrimination played a role in producing the gap.

Initially when these changes were announced publicly, UniversityNZ CEO Chris Wheelen suggested that these changes would dilute the excellence and shift the purpose of the fund, arguing that Māori and Pacific research needed a separate funding incentive. ${ }^{25}$ Interestingly, Chris Wheelan also noted that "there's always a risk that you end up with a system that ends up being gamed," suggesting that universities were already considering what changes they would need to implement to benefit from the proposed changes. Without making any changes, the university sector would lose 0.5 percent of PBRF funding with the additional weighting of 2 for evidence portfolios submitted by staff who identify as Māori or Pacific, and 0.2 percent of PBRF funding with the additional weighting of 2.5 for evidence portfolios assessed by the Māori knowledge and development panel or Pacific research panel. Importantly, the cabinet briefing outlines that this intervention is a purposeful attempt to bridge the "gap" for Māori and Pacific academic hires. 


\begin{tabular}{|l|l|l|l|l|c|}
\hline TEO & $\begin{array}{l}\text { Estimated } \\
2019 \\
\text { Funding } \\
\text { Allocation }\end{array}$ & $\begin{array}{l}\text { Difference in } \\
\text { Funding for } \\
\text { Evidence } \\
\text { Portfolio }\end{array}$ & $\begin{array}{l}\text { Difference in } \\
\text { Funding for } \\
\text { Māori or } \\
\text { Pacific } \\
\text { Identified } \\
\text { Staff }\end{array}$ & $\begin{array}{l}\text { Total } \\
\text { Difference in } \\
\text { Funding }\end{array}$ & $\begin{array}{l}\text { Percentage } \\
\text { Difference in } \\
\text { Funding }\end{array}$ \\
\hline $\begin{array}{l}\text { University of } \\
\text { Auckland }\end{array}$ & $\$ 47,957,092$ & $\$ 215,694$ & $\$ 694,525$ & $\$ 910,219$ & $2 \%$ \\
\hline $\begin{array}{l}\text { University of } \\
\text { Waikato }\end{array}$ & $\$ 8,555,916$ & $\$ 1,144,682$ & $\$ 341,093$ & $\$ 1,485,775$ & $17 \%$ \\
\hline $\begin{array}{l}\text { Massey } \\
\text { University }\end{array}$ & $\$ 22,290,599$ & $-\$ 665,409$ & $-\$ 144,811$ & $-\$ 810,220$ & $-4 \%$ \\
\hline $\begin{array}{l}\text { Victoria } \\
\text { University of } \\
\text { Wellington }\end{array}$ & $\$ 19,424,883$ & $-\$ 173,910$ & $-\$ 440,127$ & $-\$ 614,037$ & $-3 \%$ \\
\hline $\begin{array}{l}\text { University of } \\
\text { Canterbury }\end{array}$ & $\$ 14,497,735$ & $-\$ 564,802$ & $-\$ 520,688$ & $-\$ 1,085,490$ & $-7 \%$ \\
\hline $\begin{array}{l}\text { Lincoln } \\
\text { University }\end{array}$ & $\$ 4,572,602$ & $-\$ 61,378$ & $\$ 79,184$ & $\$ 17,806$ & $0 \%$ \\
\hline $\begin{array}{l}\text { University of } \\
\text { Otago }\end{array}$ & $\$ 35,782,703$ & $-\$ 1,907,363$ & $-\$ 991,079$ & $-\$ 2,898,442$ & $-8 \%$ \\
\hline $\begin{array}{l}\text { Auckland } \\
\text { University of } \\
\text { Technology }\end{array}$ & $\$ 12,625,510$ & $\$ 318,015$ & $\$ 192,131$ & $\$ 192,131$ & $2 \%$ \\
\hline
\end{tabular}

Table 1. Predicted Funding Differentials with Implementation of Additional Weighting of 2 and 2.5 for Māori and Pacific Identified Staff and Māori and Pacific Panel Assessed Portfolios Respectively ${ }^{26}$

How Many Pacific Peoples Do We Need to Change the Disciplines/Universities/Sector?

Aotearoa-New Zealand's PBRF review found that for our system to be equitable, we need 450 more Pacific academics employed in permanent full-time positions across our universities. ${ }^{27}$ This same report noted that at our current rate of change Pacific would reach population parity in our research workforce by 2150 . If we understand a generation as 30 years, it is going to take just over four generations, all things going to plan, to see this shift. UniversitiesNZ noted that if parity of participation for Pacific students was achieved, an extra 1,100 Pacific students would be completing degrees each year. ${ }^{28}$ Arguments that centre on parity or population matching provide blunt tools to hold our universities accountable. We can track progress through the utilisation of numbers, and then, if necessary, use these numbers to argue for more resources. However, literature on fundamentally shifting disciplines/universities/sectors suggests that simple population matching of underrepresented groups will not result in the change that we perhaps desire as Pacific peoples. 


\section{Disrupting Disciplines}

It becomes increasingly clear that while critical mass/parity/population-matching narratives ${ }^{29}$ enable us to hold those in power accountable, if we stop the conversation at that point we will fundamentally miss a key question: why? ${ }^{30}$ When we ask "why?" instead of "how many?" we enable conversations about the different structures that operate to exclude us. "Why" enables us to identify the sources of the disparity in the first place. There are significant amounts of work into how and why Indigenous knowledges and racialised bodies are excluded from universities, and we are increasingly seeing work from Pacific scholars that provide accounts of the experience of being excluded. ${ }^{31}$ However, further work is needed if we are to challenge the foundational structures that exclude us: the why.

If our aim is to disrupt disciplines that have at different moments excluded us, studied us, ignored us, begrudgingly included us, or misunderstood us, then it perhaps becomes necessary to acknowledge that part of this means interrogating the foundations on which our disciplines have been built. Just as Epeli Hau' ofa laid bare the foundations of anthropology in the Pacific within "Our Sea of Islands," we must consider our role in disrupting the different disciplines that confine us. ${ }^{32}$ This is a wider project for many Indigenous and racialised scholars within their disciplines. As shown by Bhambra's "connected sociologies" project, unsettling and reconstituting standard processes of knowledge production is a necessary part of disrupting our disciplines. ${ }^{33}$

\section{Where Does This Leave Us?}

There are a number of questions I wish to raise in this section. The first requires engaging in Nancy Leong's work on the concept of racial capitalism. ${ }^{34}$ Leong argues that "efforts to create racial diversity usually begin — and often end - with increasing the number of nonwhite people within a group or institution. As a result, nonwhiteness has acquired a unique value because, in many contexts, it signals the presence of the prized characteristic of diversity." 35 In short, Pacific bodies become valuable to the university as they give the appearance of valuing diversity, which holds significant cultural value at this time. For example, having our community members on posters, giving public talks, and being visible generally enables our universities to look as if they embrace diversity concepts and, therefore, to reap the financial and social reward this brings without having to fundamentally change anything. ${ }^{36}$ As discussed, Pacific peoples' capital is not theoretical to our universities. Our students are worth additional funding, and the recent PBRF changes mean that like our students, Pacific academics are also worth money to the institution. The question then becomes, how do we leverage this increased value within our institutions and across the sector to engage in deep foundational change as opposed to window dressing?

Leong also raises the concern that progress for non-white people only occurs when it benefits white people. ${ }^{37}$ In the case of Pacific peoples and New Zealand universities, the sudden shift to recruiting Pacific students stemmed from increased funding levels, just as the sudden announcements of academic jobs with a Pacific focus can be tied to the release of the PBRF review. This should cause us to critically engage in the so-called "gift" of the university. ${ }^{38}$ Pacific scholars have built on international literature to show how Pacific peoples experience the New Zealand education system as something that has been given to them and therefore are expected to show a level of gratitude for their inclusion. ${ }^{39}$ However, not only is this gratitude enforced through colonial mechanisms; it is also wholly unjustified. As outlined above, our presence in New Zealand universities has a financial reward attached. We need to ask ourselves 
why it is that our institutions acted once there was a financial reward and what it is about our institutions' foundational values that expects our gratitude for our inclusion?

Unfortunately, the value we bring to the university is not without cost. Musser outlines that it is in racialised bodies' value and rarity that we become specimens to the university: we become commodities to be collected. ${ }^{40}$ Importantly, using the language of specimen enables us to articulate the ways in which "money, science, and desire intersect to confer value on an object." 41 This further opens the conversation include discussion of how universities are happy to engage in polite inclusivity conversations as it distracts us from the much needed conversation about, and act of, the redistribution of resources and power. ${ }^{42}$

Pacific women have reported on the excess labour of ensuring that they present a friendly face of diversity and the negative ramifications of pushing beyond polite inclusivity. ${ }^{43}$ When PBRF changes were first discussed, I sat in meetings where the panic and tension around redistributing the PBRF funds to reflect more value on Māori and Pacific knowledges and communities was discussed in depth, and plans to slow down any progress towards this were discussed. This underscores how Pacific bodies are only desired when we fail to challenge power and resourcing. We are only desired when we are happy to be used on a billboard or public talk as a signal that the university is an inclusive and progressive place. The university's desire for the presence of Pacific bodies only when we are docile begs the question of how we will know when universities have shifted beyond only accepting us if we engage in a disavowal of the need for redistribution? Is it when we have population matching? Is it when we have a Pacific vice chancellor? Is it when we have parity of outcomes? Is it something we will just "know"?

We also must not be naïve: some of us benefit from the foundations of our university. An analysis of the pay gap between Māori/Pacific and non-Māori/Pacific shows that when performance, research field, and age are accounted for, promotions and pay reflect an ethnicity and gender gap. ${ }^{44}$ At 5, 10, and 15 years after first submitting to PBRF, 29 percent of Māori/Pacific men in our universities have been promoted to professor, whereas 25 percent of Māori/Pacific women in our universities have been. For Pākehā men in our universities, the rate is 39 percent. Māori/Pacific men earn \$.91 for every \$1 that non-Māori/Pacific men earn, whereas Māori/Pacific women earn $\$ .85$ for every $\$ 1$ that non-Māori and Pacific men earn. This is significant, as it shows that even within Pacific communities there are inequities, and that while some of us may see an urgent need for interventions others may slow or halt progression, as the system currently motivates them to maintain the status quo through the benefits they receive. This leads me to raise the question, how do we advocate for change when those who benefit from the current system may not wish to see the change?

Finally, we need to engage in accountability measures. The governmental levers that we have for change are not often used by our communities to hold our institutions to account. For instance, despite there being a clear indication that each university is given specific targets that universities must achieve in order to receive equity funding, these targets are not easily available to the public. Therefore, how do we know whether our universities are meeting these targets, whether these targets are ambitious enough, or whether these targets continue the slow march to polite inclusion? As Pacific researchers we are time poor; the pressures and commitments that we are laden with leave us with little time to engage in these critical conversations. However, as Graham Hingangaroa Smith has often said, when it comes to systems level change, we must be aware of the politics of distraction, where we can get wrapped 
up in the day-to-day concerns instead of taking on the wider structural inequities. ${ }^{45}$ This means creating opportunities to have critical conversations and ask uncomfortable questions in an effort to shift the education sector. These critical conversations and uncomfortable questions are not new. We have others we can turn to, both at home and around the globe, to see how they are engaging with the idea of change in our education systems, and whether we want inclusion at any cost. ${ }^{46}$

\section{Conclusion}

As outlined above, there are a number of different levers that can be used to bring about change in our universities. However, it is unclear whether these levers enable the deep structural change that is needed to disrupt how Pacific communities and our knowledge base are valued by our universities. The status quo of investing in polite political change that enables inclusion of Pacific bodies is not enough to drive the structural change needed. Instead, we must engage in a critique of our institutions and these levers to both call them to account and challenge them to move beyond easily measurable milestones that only result in glacial inclusive change, instead of the much-needed deep structural change.

\footnotetext{
${ }^{1}$ Ministry of Education, "Pasifika Education Plan 2013-2017," 2013, https://assets.education.govt.nz/public/Documents/Ministry/Strategies-andpolicies/PasifikaEdPlan2013To2017V2.pdf.

${ }^{2}$ Ministry of Education, Action Plan for Pacific Education 2020-2030: Full Report (June 2020), https://conversation.education.govt.nz/conversations/action-plan-for-pacific-education/.

${ }^{3}$ Ministry of Education, Action Plan for Pacific Education 2020-2030, 14.

${ }^{4}$ See, for example: the University of Auckland's Equity Policy, https://www.auckland.ac.nz/en/about/the-university/how-university-works/policy-andadministration/equity/equity-policy-and-procedures-.html; Auckland University of Technology's
} Diversity Roadmap, https://www.aut.ac.nz/about/social-responsibility/diversity; Massey University's Equal Employment Opportunities Policy, https://www.massey.ac.nz/massey/fms/PolicyGuide/Documents/e/equal-employment-opportunitiespolicy.pdf; Waikato University's Equal Employment Opportunity Policy (website unavailable at time of publication); Victoria University of Wellington's Equity Diversity and Inclusion Framework, https://www.wgtn.ac.nz/documents/policy/academic/equity-diversity-and-inclusion-framework.pdf; University of Canterbury's Equal Employment Opportunity Policy, https://www.canterbury.ac.nz/about/governance/ucpolicy/staff/equal-employment-opportunitypolicy/; Lincoln University's Equal Employment Opportunity Policy, https://www.lincoln.edu/sites/default/files/pdf/hr/policies/HRM-123-DiversityEEO.pdf; and Otago University's Pacific Strategic Framework, https://www.otago.ac.nz/otago059716.pdf.

${ }^{5}$ EFT is calculated by measuring the points or credits of study that each student undertakes, as a portion of full-time study. For example, a student studying part time, completing over the course of a year one half of the points that would count as full-time study, would be measured as 0.5 EFT.

${ }^{6}$ Tertiary Education Commission, "Equity Funding for 2022," 2021, https://www.tec.govt.nz/funding/funding-and-performance/funding/fund-finder/equityfunding/equity-funding-for-2022/.

${ }^{7}$ University of Auckland, Equity Profile 2020 (2021), https://www.auckland.ac.nz/content/dam/uoa/auckland/about-us/equity-at-the-university/plansreports-reviews/University\%20of\%20Auckland\%20Equity\%20Profile\%202020\%20-\%20Final.docx. ${ }^{8}$ Tertiary Education Commission, "Equity Funding," 2021, https://www.tec.govt.nz/funding/fundingand-performance/funding/fund-finder/equity-funding. 
${ }^{9}$ Cash Ahenakew and Sereana Naepi, "The Difficult Task of Turning Walls into Tables," in Sociocultural Realities: Exploring New Horizons, ed. Melinda Webber, Sonja Macfarlane, and Angus Macfarlane (Christchurch: University of Canterbury Press, 2015), 181-94; Zaine Akuhata-Huntington et al., "COVID-19 and Indigenous Resilience," Higher Education Research and Development 39, no. 7 (2020): 1377-83; Airini et al., "Teaching for Student Success: Promising Practices in University Teaching," Pacific-Asian Education Journal 23, no. 1 (2011): 71-90; Simon Barber and Sereana Naepi, "Sociology in a Crisis: Covid-19 and the Colonial Politics of Knowledge Production in Aotearoa New Zealand," Journal of Sociology 56, no. 4 (2020): 693-703; Reremoana Theodore et al., "Equity in New Zealand University Graduate Outcomes: Māori and Pacific Graduates," Higher Education Research and Development 37, no. 1 (2018): 206-21; Reremoana Theodore et al., "Pacific University Graduates in New Zealand: What Helps and Hinders Completion," AlterNative: An International Journal of Indigenous Peoples 14, no. 2 (2018): 138-46; Tara G. McAllister et al., "Glass Ceilings in New Zealand Universities: Inequities in Māori and Pacific Promotions and Earnings," MAI Journal: A New Zealand Journal of Indigenous Scholarship 9, no. 3 (2020): 272-85; Tara G. McAllister et al., "Under-represented and Overlooked: Māori and Pasifika Scientists in Aotearoa New Zealand's Universities and Crown-research Institutes," Journal of the Royal Society of New Zealand (2020), DOI: 10.1080/03036758.2020.1796103; Sereana Naepi, "Why Isn't My Professor Pasifika: A Snapshot of the Academic Workforce in New Zealand Universities," MAI Journal: A New Zealand Journal of Indigenous Scholarship 8 (2019): 219-34; Sereana Naepi, "“I Didn't Come to Play': Pasifika Women in the Academy," in Critical Reflections and Politics on Advancing Women in the Academy, ed. Taima Moeke-Pickering, Sheila Cote-Meek, and Ann Pegoraro (IGI Global, 2020), 52-69; Sereana Naepi, "Pacific Women's Experiences Working in Universities in Aotearoa New Zealand," Higher Education Research and Development 40, no. 1 (2021); Sereana Naepi et al., "The Pakarau 'Pipeline': Māori and Pasifika Pathways within the Academy," New Zealand Annual Review of Education 24 (2020): 142-59; Sereana Naepi et al., "A Cartography of Higher Education: Attempts at Inclusion and Insights from Pasifika Scholarship in Aotearoa New Zealand," in Global Teaching: Southern Perspectives on Teachers Working with Diversity, ed. Carol Reid and Jae Major (New York: Palgrave Macmillan, 2017), 81-99; Sereana Naepi et al., "Where Are We Now? Patterns of Māori and Pasifika Enrolment in the Natural and Physical Science and Society and Culture Fields in Aotearoa New Zealand," Higher Education Research and Development 40, no. 1 (2021): 90-103; Patrick Thomsen et al., "In Our Own Words: Pacific Early Career Academics (PECA) and Pacific Knowledges in Higher Education Pedagogical Praxis," Higher Education Research and Development 40, no. 1 (2021): 49-62.

${ }^{10}$ Marcia Leenen-Young, "Pasifika Students and Learning to Learn at University," MAI Journal: A New Zealand Journal of Indigenous Scholarship 9, no. 1 (2020): 70-93; Marcia Leenen-Young et al., "“Pillars of the Colonial Institution Are Like a Knowledge Prison': The Significance of Decolonizing Knowledge and Pedagogical Practice for Pacific Early Career Academics in Higher Education," Teaching in Higher Education (2021): DOI 10.1080/13562517.2021.1928062; Ahenakew and Naepi, "The Difficult Task of Turning Walls into Tables"; Unaisi Nabobo-Baba, "Decolonising Framings in Pacific Research: Indigenous Fijian Vanua Research Framework as an Organic Response," AlterNative: An International Journal of Indigenous Peoples 4, no. 2 (2008): 141-54; Tamasailau M. Suaalii-Sauni, "Critiquing Pasifika Education at University," AlterNative: An International Journal of Indigenous Peoples 4, no. 1 (2008): 15-23; Tamasailau Suaalii-Sauni and Saunimaa Ma FuluAiolupotea, "Decolonising Pacific Research, Building Pacific Research Communities and Developing Pacific Research Tools: The Case of the Talanoa and the Faafaletui in Samoa," Asia Pacific Viewpoint 55, no. 3 (2014): 331-44.

${ }^{11}$ Naepi, "Why Isn't My Professor Pasifika"; Sereana Naepi et al., "Why isn't my Professor Māori or Pacific? Data Update," preprint, University of Auckland, 2020,

https://auckland.figshare.com/ndownloader/files/25441730.

${ }^{12}$ Naepi et al., "Where Are We Now?"

${ }^{13}$ Hilary Dansey Dutton et al., "“We're All in It Together': Māori and Pacific Student Voices on Ethnic-specific Equity Programmes in a New Zealand University," MAI Journal: A New Zealand Journal of Indigenous Scholarship 5, no. 1 (2016): 3-16; David Tokiharu Mayeda et al., "“You've 
Gotta Set a Precedent': Māori and Pacific Voices on Student Success in Higher Education," AlterNative: An International Journal of Indigenous Peoples 10, no. 2 (2014): 165-79; Danielle Amare Kahurangi Waiari et al., "Stoking the Fires for Māori and Pacific Student Success in Psychology," Higher Education Research and Development 40, no. 1 (2021): 117-31.

${ }^{14}$ Airini et al., "Teaching for Student Success"; Cherie Chu, Ivy Samala Abella, and Seann Paurini, Educational Practices that Benefit Pacific Learners in Tertiary Education (Wellington: Ako Aotearoa, National Centre for Tertiary Teaching Excellence, 2013); Dutton et al., "We're All in It Together"; J Nanai et al., "Through Pacific/Pasifika Lens to Understand Students Experiences to Promote Success Within New Zealand Tertiary Environment," Sociology Study 7, no. 6 (2017): 293314; Tasileta Teevale and Alapasita Teu, "What Enabled and Disabled First-year Pacific Student Achievement at University?," Journal of the Australian and New Zealand Student Services Association 26, no. 1 (2018): 15-27; Theodore et al., "Pacific University Graduates in New Zealand"; Waiari et al., "Stoking the Fires for Māori and Pacific Student Success in Psychology"; Erena Wikaire et al., "Predictors of Academic Success for Māori, Pacific and Non-Māori Non-Pacific Students in Health Professional Education: A Quantitative Analysis," Advances in Health Sciences Education 22, no. 2 (2017): 299-326; Leenen-Young, "Pasifika Students and Learning to Learn at University." ${ }^{15}$ Naepi et al., "Where Are We Now?"

${ }^{16}$ Joanna Kidman and Cherie Chu, "We're Not the Hottest Ethnicity': Pacific Scholars and the Cultural Politics of New Zealand Universities," Globalisation, Societies and Education 17, no. 4 (2019): 489-99.

${ }^{17}$ Tara G. McAllister et al., "Parity During Parenthood: Comparing Paid Parental Leave Policies in Aotearoa/New Zealand's Universities," Women's Studies Journal 35, no. 1 (November 2021): 4-20; Naepi, "Pacific Women's Experiences Working in Universities in Aotearoa New Zealand." ${ }^{18}$ Thomsen et al., "In Our Own Words."

${ }^{19}$ Barber and Naepi, "Sociology in a Crisis"; Naepi, "Why Isn't My Professor Pasifika"; Sereana Naepi, "Pacific Research Methodologies," in Oxford Research Encyclopedia of Education, ed. George Noblit (New York: Oxford University Press, 2019), https://oxfordre.com/education; Naepi, "I Didn't Come to Play"; Naepi, "Pacific Women's Experiences Working in Universities in Aotearoa New Zealand"; Naepi et al., "A Cartography of Higher Education"; Joanna Kidman, "Whither Decolonisation? Indigenous Scholars and the Problem of Inclusion in the Neoliberal University," Journal of Sociology 56, no. 2 (2020): 247-62; Joanna Kidman and Cherie Chu, "Scholar Outsiders in the Neoliberal University: Transgressive Academic Labour in the Whitestream, "New Zealand Journal of Educational Studies 52, no. 1 (2017): 7-19; Kidman and Chu, "We're not the Hottest Ethnicity."

${ }^{20}$ Leenen-Young et al., "Pillars of the Colonial Institution are like a Knowledge Prison."

${ }^{21}$ Naepi, “Why Isn’t My Professor Pasifika?"; Naepi et al., "Why Isn’t My Professor Māori or Pacific? Data Update."

${ }^{22}$ Te Tai Ōhanga The Treasury, "Estimates of Appropriations: Vote Tertiary Education-Education and Workforce Sector-Estimates 2020/21," 2020, https://www.treasury.govt.nz/sites/default/files/2020-05/est20-v2-tered.pdf.

${ }^{23}$ Tertiary Education Commission, "Performance-Based Research Fund Improvements," 2021, https://www.tec.govt.nz/news-and-consultations/performance-based-research-fund-improvements/.

${ }^{24}$ Linda Tuhiwai Smith et al., E koekoe te tūì, e ketekete te kākā, e kūkū te 27ereru: The Report of the PBRF Review Panel (2020), https://www.education.govt.nz/assets/Documents/Furthereducation/PBRF-Review/The-Report-of-the-PBRF-Review-panel-E-koekoe-te-tuie-ketekete-tekaka..-.pdf.

25 “Hiring More Māori Researchers 'Needs Its Own Dedicated Funding,'” Radio New Zealand, 2021, https://www.rnz.co.nz/news/national/446190/hiring-more-maori-researchers-needs-its-own-dedicatedfunding.

${ }^{26}$ Hon. Jenny Salesa, "Report Back on the Performance-Based Research Fund Review, 2020, https://www.education.govt.nz/assets/Documents/Further-education/PBRF-Review/CAB-20-MIN0352-Report-of-the-Cabinet-Social-Wellbeing-Committee-Minute-....pdf.

${ }^{27}$ Smith et al., E koekoe te tūì, e ketekete te kākā, e kūkū te 28ereru. 
${ }^{28}$ UniversitiesNZ, "Achieving Parity for Māori and Pasifika—The University Sector View," 2018, https://www.universitiesnz.ac.nz/sites/default/files/UNZ\%20Parity\%20Discussion\%20Paper\%200ne \%20\%28Aug\%202018\%29.pdf.

${ }^{29}$ Critical mass: an agreed number of Pacific people's in the institution for change to happen; parity: Pacific achieving at the same rate as everybody else; population matching: the number of Pacific people in the academy matching our population rates.

${ }^{30}$ Gloria Ladson-Billings, "Lack of Achievement or Loss of Opportunity," in Closing the Opportunity Gap: What America Must do to Give Every Child an Even Chance, ed. Prudence L. Carter and Kevin G. Welner (New York: Oxford University Press, 2013): 11-22; Gloria Ladson-Billings, "Pushing Past the Achievement Gap: An Essay on the Language of Deficit," The Journal of Negro Education (2007): 316-23; Lori Patton Davis and Samuel D. Museus, "What is Deficit Thinking? An Analysis of Conceptualizations of Deficit Thinking and Implications for Scholarly Research," NCID Currents 1, no. 1 (2019), http://dx.doi.org/10.3998/currents.17387731.0001.110.

${ }^{31}$ Sara Ahmed, On Being Included: Racism and Diversity in Institutional Life (Durham, NC: Duke University Press, 2012); Marie Battiste, Lynne Bell, and Len M. Findlay, "Decolonizing Education in Canadian Universities: An Interdisciplinary, International, Indigenous Research Project," Canadian Journal of Native Education 26, no. 2 (2002): 82-95; Marie Battiste et al., Dissident Knowledge in Higher Education (University of Regina Press, 2018); Vanessa de Oliveira Andreotti et al., "Mapping Interpretations of Decolonization in the Context of Higher Education," Decolonization: Indigeneity, Education and Society 4, no. 1 (2015): 21-40; David Fa'avae, "Tatala 'a e Koloa 'o e To'utangata Tonga: A Way to Disrupt and Decolonise Doctoral Research," MAI Journal: A New Zealand Journal of Indigenous Scholarship 8, no. 1 (2019): 3-15; Adam Gaudry and Danielle Lorenz, "Indigenization as Inclusion, Reconciliation, and Decolonization: Navigating the Different Visions for Indigenizing the Canadian Academy," AlterNative: An International Journal of Indigenous Peoples 14, no. 3 (2018): 218-27; Kidman, "Whither Decolonisation?"; Martin Nakata et al., "Decolonial Goals and Pedagogies for Indigenous Studies," Decolonization: Indigeneity, Education and Society 1, no. 1 (2012): 120-40; Linda Tuhiwai Smith, Decolonizing Methodologies: Research and Indigenous Peoples (London: Zed Books, 2013); Sharon Stein, "Beyond Higher Education As We Know It: Gesturing Towards Decolonial Horizons of Possibility," Studies in Philosophy and Education 38, no. 2 (2019): 143-61; Suaalii-Sauni and Fulu-Aiolupotea, "Decolonising Pacific Research, Building Pacific Research Communities and Developing Pacific Research Tools"; Konai Helu Thaman, "Decolonizing Pacific Studies: Indigenous Perspectives, Knowledge, and Wisdom in Higher Education," The Contemporary Pacific 15, no. 1 (2003): 1-17; Eve Tuck, "Biting the University That Feeds Us," in Dissident Knowledge in Higher Education, ed. Marc Spooner and James McNinch (Regina: University of Regina Press, 2018), 149-67.

${ }^{32}$ Epeli Hau'ofa, "Our Sea of Islands," The Contemporary Pacific 6, no. 1 (1994): 147-61; Epeli Hau'ofa, We Are the Ocean: Selected Works (Honolulu: University of Hawaii Press, 2008).

${ }^{33}$ Gurminder K. Bhambra, Connected Sociologies (London: Bloomsbury Publishing, 2014); Gurminder K. Bhambra, "Postcolonial and Decolonial Dialogues," Postcolonial Studies 17, no. 2 (2014): 115-21.

${ }^{34}$ Nancy Leong, "Racial Capitalism," Harvard Law Review 126, no. 8 (2012): 2151-226; Nancy Leong, "Reflections on Racial Capitalism," Harvard Law Review Forum 127 (2013): 32-38.

${ }^{35}$ Leong, "Racial Capitalism," 2168-69.

${ }^{36}$ Amber Jamilla Musser, "Specimen Days: Diversity, Labor, and the University," Feminist Formations 27, no. 3 (2015): 1-20.

${ }^{37}$ Leong, "Racial Capitalism."

${ }^{38}$ Rauna Kuokkanen, Reshaping the University: Responsibility, Indigenous Epistemes, and the Logic of the Gift (Vancouver: UBC Press, 2011).

${ }^{39}$ Marcia Leenen-Young and Sereana Naepi, "Gathering Pandanus Leaves: Colonization, Internationalization and the Pacific," Journal of International Students 11, no. S1 (2021): 15-31; Naepi et al., "A Cartography of Higher Education."

${ }^{40}$ Musser, "Specimen Days."

${ }^{41}$ Musser, "Specimen Days," 2. 
${ }^{42}$ Roderick A. Ferguson, The Reorder of Things: The University and Its Pedagogies of Minority Difference (Minneapolis: University of Minnesota Press, 2012).

${ }^{43}$ Naepi, "I Didn't Come to Play"; Naepi, "Pacific Women's Experiences Working in Universities in Aotearoa New Zealand."

${ }^{44}$ McAllister et al., "Glass Ceilings in New Zealand Universities."

${ }^{45}$ Graham Hingangaroa Smith, "Kaupapa Maori Theory: Theorizing Indigenous Transformation of Education and Schooling," (paper presented at the Kaupapa Maori Symposium, Hyatt Hotel, Auckland, 2003).

${ }^{46}$ Graham Hingangaroa Smith and Linda Tuhiwai Smith, "Doing Indigenous Work: Decolonizing and Transforming the Academy," in Handbook of Indigenous Education, ed. E. McKinley and Linda Tuhiwai Smith (Singapore: Springer, 2018), 1075-1101; Glen Sean Coulthard, Red Skin, White Masks: Rejecting the Colonial Politics of Recognition (Minneapolis: University of Minnesota Press, 2014). 